\title{
Factors affecting acrylamide mitigation in fried potatoes
}

\author{
Pham Thi Hoan, Hoang Minh Hao*
}

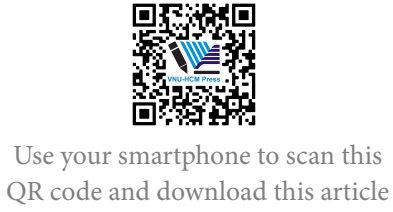

Faculty of Chemical and Food Technology, Ho Chi Minh City University of Technology and Education, Ho Chi Minh City, Vietnam, 01 Vo Van Ngan Street, Linh Chieu Ward, Thu Duc District, Ho Chi Minh City, Vietnam

\section{Correspondence}

Hoang Minh Hao, Faculty of Chemical and Food Technology, Ho Chi Minh City University of Technology and Education, Ho Chi Minh City, Vietnam, 01 Vo Van Ngan Street, Linh Chieu Ward, Thu Duc District, Ho Chi Minh City, Vietnam

Email: haohm@hcmute.edu.vn

History

- Received: 2020-03-28

- Accepted: 2020-06-25

- Published: 2020-06-30

DOI : 10.32508/stdj.v23i2.1906

\section{Check for updates}

\section{Copyright}

(c) VNU-HCM Press. This is an openaccess article distributed under the terms of the Creative Commons Attribution 4.0 International license.

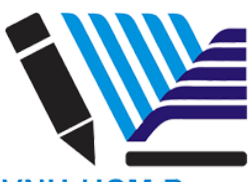

VNU-HCM Press

\begin{abstract}
Introduction: Recent findings of acrylamide, a carcinogenic agent to humans, in foods have led to great efforts to elucidate the mechanisms of acrylamide formation and its mitigation. The acrylamide was generated during the browning process by the Maillard reaction of amino acid asparagine and reducing sugars at temperatures above $120^{\circ} \mathrm{C}$. Asparagine was determined to be a precursor of acrylamide formation. Therefore, asparagine reduction in raw materials can be taken into account to limit the acrylamide level in prepared foods. L-asparaginase has been used to consume acrylamide precursor by catalyzing the conversion of asparagine into aspartic acid and ammonia. Several factors including enzyme concentration, $\mathrm{pH}$, temperature and frying time can influence the efficiency of acrylamide mitigation by enzyme. In the present work, we selected potatoes as raw materials to investigate the effects of factors on the acrylamide mitigation in fried potatoes. Methods: By pre-treating potato strips in different conditions of enzyme concentrations, $\mathrm{pH}$, temperature and frying time, the effects of these parameters on acrylamide levels in fried products were evaluated by measuring UV-Vis spectra of sample solutions containing acrylamide. The maximum absorbance values at $224 \mathrm{~nm}$ were used to determine the acrylamide concentrations by calculation from a calibration curve. Experimental data were statistically analyzed by one-way ANOVA. Colorspace measurements were performed to describe the differences in colors of the fried products after various frying times. Results: A calibration curve was established to determine the acrylamide content of sample solutions via their maximum absorbance values. Pre-treatment of potato strips with a solution of $1.0 \mathrm{IU} / \mathrm{mL}$ asparaginase at $37^{\circ} \mathrm{C}, \mathrm{pH} 7.3$, for $30 \mathrm{~min}$ led to a $45.6 \%$ reduction of acrylamide in French fries compared to a solution without enzyme. The optimum $\mathrm{pH}$ value for the most efficient enzyme activity was 7.3. Frying time ranging from 1.0 to $6.0 \mathrm{~min}$ increased acrylamide content and induced a darker appearance product. Conclusions: By using UV-Vis measurements, we demonstrated the effects of factors on L-asparaginase based acrylamide mitigation in fried potatoes. The conditions which gave the lowest acrylamide concentrations were assessed. The results could be applicable for commercial processes to minimize acrylamide content in prepared potatoes.
\end{abstract}

Key words: Fried potatoes, acrylamide, asparagine, L-asparaginase, Maillard reaction

\section{INTRODUCTION}

Fried potatoes are a common food item served at restaurants and at home. They are products of a deep fat frying process that involves submerging potato strips in extremely hot oil until the products become hot and crispy on the outside and cooked safely in the center. The discovery in 2002 of high levels of acrylamide, a carcinogenic agent to humans, in a wide range of fried foods (e.g. French fries), bread and coffee has led to intense concerns ${ }^{1,2}$. Acrylamide causes potential cancer risk through dietary exposure. Therefore, acrylamide reduction in foods has been extensively studied. Acrylamide is formed from asparagine and reducing sugars in the Maillard reaction which typically occurs at temperatures above $120^{\circ} \mathrm{C}$ and is required for desirable color, flavor and aroma production $^{3-7}$. In processing industries for potato chips, it is possible to reduce the acrylamide precursor levels, e.g. asparagine or reducing sugars, either by blanching (immersing in boiling water), or soaking the raw materials in water or acidic solutions $^{8}$. The removal of acrylamide from fried food products is impractical. Therefore, strategies have focused on reducing acrylamide formation from precursors. L-asparaginase can selectively remove the free asparagine by converting it into aspartic acid and ammonia $^{9-12}$.

To the best of our knowledge, there are no studies on the acrylamide reduction process in fried potatoes in Vietnam by systematically varying factors such as asparaginase concentration, $\mathrm{pH}$, temperature and frying time. Here, we selected Solanum tuberosum (Solanaceae) as a potato cultivar to investigate the effects of factors on acrylamide formation ${ }^{13}$. The objectives are to demonstrate: (i) the effect of enzyme treatment on reducing the asparagine precursor for 
acrylamide formation; (ii) the influences of factors on acrylamide reduction in fried potatoes using $\mathrm{L}$ asparaginase.

\section{MATERIALS AND METHODS}

\section{Preparation of potato strips}

Potatoes were processed according to a publication by Pedreschi with some modification ${ }^{14}$. Potatoes $(0.3$ $\mathrm{kg} /$ tuber) were gathered from a farmhouse in Lam Dong Province, then washed and peeled. Strips of cross-sections of $1.0^{\prime} 1.0^{\prime} 3.0 \mathrm{~cm}$ were cut from the pith of the potato tubers by using a knife and a ruler. Strips were immersed in a $2.5 \% \mathrm{NaCl}$ solution at $35^{\circ} \mathrm{C}$ for $10 \mathrm{~min}$ and dried at $65{ }^{\circ} \mathrm{C}$ for $20 \mathrm{~min}$ to remove moisture on the surface. Pre-treated potato strips were finally stored at $8{ }^{\circ} \mathrm{C}$ prior to being treated with enzyme in different conditions. Potato samples were then treated with L-asparaginase with different treatment conditions (enzyme concentration, temperature, $\mathrm{pH}$ and frying time). The treated potato samples were fried at $190 \pm 5{ }^{\circ} \mathrm{C}$ for 6 minutes. The frying temperature was controlled by Digital Infrared Thermometer Temperature Gun (Extech 42512, China). Afterward, the samples were oiled out, cooled and prepared for further experiments. In all experiments, control samples were pre-treated at a temperature of $37^{\circ} \mathrm{C}$, at $\mathrm{pH} 7.3$, for $30 \mathrm{~min}$ without adding enzyme. L-asparaginase enzyme (freeze-dried powder, $500 \mathrm{IU}$, purified from Escherichia coli ASI.357 and greater than $96.0 \%$ in purity) was purchased from ProSpecTany TechnoGene Ltd. (Israel). Upon reconstitution, the enzyme was stored at $4{ }^{\circ} \mathrm{C}$. Acrylamide (> 99\%, Acros Organics, Belgium) was used to build a calibration curve for determining the concentration of acrylamide in unknown samples. Stock solution $(100 \mathrm{mg} / \mathrm{mL})$ was prepared by dissolving acrylamide in double distilled water. A range of concentrations from 5.0 to $35.0 \mathrm{mg} / \mathrm{mL}$ of acrylamide solutions was prepared for UV-Vis measurements. The absorbance values at $224 \mathrm{~nm}$ of solutions were used to plot a graph of absorbance (Abs) versus wavelength ( $\mathrm{nm}$ ). The linear regression equation was obtained from the set of experimental data points.

\section{UV-Vis measurements}

Prior to scanning the UV-Vis spectra (UH5300 UV - Vis Spectrophotometer, Hitachi, Japan), the extraction of acrylamide from fried potato samples was carried out according to Dange's method with a modification ${ }^{15}$. The enzyme-absorbed strip samples were ground into fine powder. A mixture of sample and water with ratio 1:20 (w/w) was centrifuged in three repetitions (4000 $\mathrm{rpm}$ for $20 \mathrm{~min}$ ) and then filtered to afford the sample solution. After that, the solution $(1 \mathrm{~mL})$ was diluted in a volumetric flask (volume 100 $\mathrm{mL}$ ) with $1 \mathrm{M} \mathrm{NaOH}$ solution. All samples were measured for their absorption spectra (in a wavelength range from 200 to $300 \mathrm{~nm}$ ) to obtain the absorbance values at maximum absorption wavelengths.

\section{Effects of enzyme concentration on acry- lamide mitigation ( ${ }^{\text {st }}$ experiment)}

A volume of $2.5 \mathrm{~mL}$ distilled water was added to the vial containing L-asparaginase to give a stock solution $(500 \mathrm{IU} / 2.5 \mathrm{~mL})$. The enzyme solutions $(2.0 \mathrm{~mL})$ at different concentrations $(0.0,0.2,1.0,1.5$ and 2.0 $\mathrm{IU} / \mathrm{mL}$ ) were prepared. Strips were immersed in the enzyme solutions at $37^{\circ} \mathrm{C}$, $\mathrm{pH} 7.3$, for 30 minutes.

\section{Effects of $\mathrm{pH}$ on acrylamide mitigation $\left(2^{\text {nd }}\right.$ experiment)}

Strips were immersed in the enzyme solutions (1.0 $\mathrm{IU} / \mathrm{mL})$, which had been selected from the 1st experiment, with the various $\mathrm{pH}$ values $(6.0,6.5,7.3$ and $8.0)$ at $37^{\circ} \mathrm{C}$ for $30 \mathrm{~min}$. The $\mathrm{pH}$ range was prepared by using a phosphate buffer $0.1 \mathrm{M}$ sodium phosphate monobasic and $0.1 \mathrm{M}$ sodium phosphate dibasic solutions; the different volume proportions were mixed together and the final volume was adjusted to $200 \mathrm{~mL}$ using deionized water. The desired $\mathrm{pH}$ values were obtained using a sensitive $\mathrm{pH}$ meter.

\section{Effects of temperature on acrylamide miti- gation ( $3^{r d}$ experiment)}

While the enzyme concentration $(1.0 \mathrm{IU} / \mathrm{mL})$ and $\mathrm{pH}$ (7.3) obtained from the two above experiments were kept constant, the temperature was changed. The solutions containing the strips were pre-treated at 30,37, 45 and $50{ }^{\circ} \mathrm{C}$ for 30 minutes.

\section{Effects of frying time on acrylamide mitiga- tion and appearance ( $4^{\text {th }}$ experiment)}

After treating with enzyme $(1.0 \mathrm{IU} / \mathrm{mL})$ at $37^{\circ} \mathrm{C}, \mathrm{pH}$ 7.3 for $30 \mathrm{~min}$, the strip samples were washed with distilled water and fried at $190 \pm 5{ }^{\circ} \mathrm{C}$ in oil for different time periods (1-6 $\mathrm{min}$ ) to evaluate the effects of frying time on acrylamide mitigation and appearance.

\section{Colorspace measurements}

The color of the potato strips was determined by a CR400 chroma meter (Minolta, Japan). The resulting colors on the fried products were compared with the ones 
of the sample for $0 \mathrm{~min}$. The $\mathrm{L}, \mathrm{a}$, and $\mathrm{b}$ values represent white/black, red/green and yellow/blue, respectively. The difference in color $(\triangle E)$ was calculated by the formula:

$\triangle E=\sqrt{\left(\left(L_{i}-L_{0}\right)^{2}+\left(a_{i}-a_{0}\right)^{2}+\left(b_{i}-b_{0}\right)^{2}\right)}$

Where, $\left(L_{0}, a_{0}, b_{0}\right)$ are the values of $\mathrm{L}, \mathrm{a}$, and $\mathrm{b}$ for the potato sample without frying, $\left(L_{i}, a_{i}, b_{i}\right)$ are $\mathrm{L}$, $a$, and $b$ values of the enzyme-treated potato samples after frying for $i$-minute.

Based on the $\triangle E$ value, the difference in color between the samples was assessed ${ }^{16}$ as: $0<\triangle E<1$ (the observer did not notice the difference in color;); $1<$ $\triangle E<2$ (only experienced observers were able to notice the difference in color); $2<\triangle E<3.5$ (inexperienced observers might notice color differences); and $\triangle E>3.5$ (there was a clear color difference between the two samples).

Each experiment was repeated three times. Experimental data was statistically analyzed by one-way ANOVA.

\section{RESULTS}

\section{Calibration curve}

In order to evaluate the efficiency of acrylamide reduction by enzyme, a calibration curve was established by fitting the experimental points, which are the absorbance values at maximum absorption wavelength $(224 \mathrm{~nm})$ of various acrylamide solutions. Figure 1 depicts the absorption spectra of acrylamide solutions at different concentrations. The inset shows a calibration curve; the calibration equation of $y=$ $0.0252 x+0.0346$ was used to determine the acrylamide concentration of the samples.

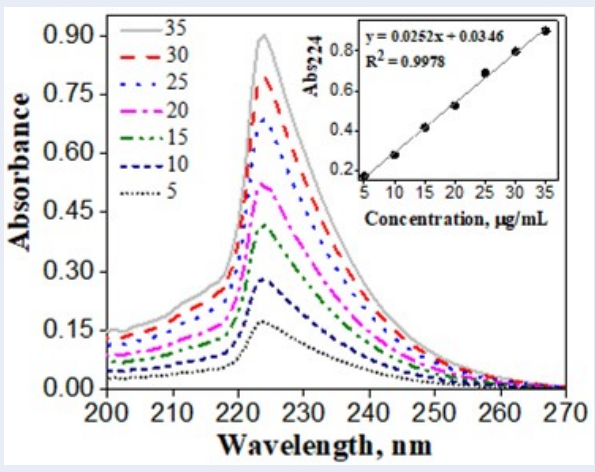

Figure 1: The absorption spectra of acrylamide solutions. The calibration curve and equation were given in the inset.

\section{Effects of enzyme concentration on acry- lamide mitigation}

A series of sample solutions pre-treated with various enzyme concentrations $(0.0,0.2,1.0,1.5$ and 2.0 $\mathrm{IU} / \mathrm{mL}$ ) was scanned for UV-Vis spectra to evaluate the effects of enzyme concentrations on the acrylamide reduction in the fried strips. Figure 2 shows the absorption spectra (top panel) containing acrylamide after pre-treatment with enzyme and frying at $190 \pm 5{ }^{\circ} \mathrm{C}$. The positions of the maximum peaks were also observed at $224 \mathrm{~nm}$. The absorbance values at $224 \mathrm{~nm}$ decreased with increasing enzyme concentrations. The acrylamide concentrations of solutions are depicted in the top panel of Figure 2. Pretreatment of raw potato strips in a $2.0 \mathrm{IU} / \mathrm{mL}$ asparaginase solution at $37^{\circ} \mathrm{C}, \mathrm{pH} 7.3$ for $30 \mathrm{~min}$, reduced acrylamide content $(13.19 \mathrm{mg} / \mathrm{mL})$ in French fries by $52.6 \%$, in comparison with a solution $(27.83 \mathrm{mg} / \mathrm{mL})$ without enzyme pre-treatment. The application of Lasparaginase in $0.2 \mathrm{IU} / \mathrm{mL}$ before heat treatment resulted in a $21.4 \%$ decrease of the acrylamide level.

\section{Effects of $\mathrm{pH}$ on acrylamide mitigation}

By varying the $\mathrm{pH}$ values of sample solutions, the effects of $\mathrm{pH}$ on acrylamide mitigation in fried strips using L-asparaginase are depicted in Figure 3. Acrylamide formation in French fries was increased by approximately $50 \%$ when $\mathrm{pH}$ values changed from 7.3 to 8.0. The results showed that when the potato strips were pre-treated in a $1.0 \mathrm{IU} / \mathrm{mL}$ asparaginase solution at $37{ }^{\circ} \mathrm{C}$ for $30 \mathrm{~min}$ at $\mathrm{pH} 6.0$ and 6.5 , the acrylamide contents were $16.96 \mathrm{mg} / \mathrm{mL}$ and $17.23 \mathrm{mg} / \mathrm{mL}$, respectively, which was higher than the value at $\mathrm{pH}$ $7.3(15.13 \mathrm{mg} / \mathrm{mL})$.

\section{Effects of the immersing temperature on acrylamide mitigation}

To evaluate the effects of temperature on enzyme activity in the acrylamide reduction process, the raw strips were submerged in the enzyme solutions at different temperatures (Figure 4). Raw potato strips were pre-treated in a $1.0 \mathrm{IU} / \mathrm{mL}$ asparaginase solution, $\mathrm{pH} 7.3$, for $30 \mathrm{~min}$ at four different temperatures. The application of L-asparaginase before frying resulted in a decrease of acrylamide level when the reactions occurred at $30^{\circ} \mathrm{C}(18.54 \mathrm{mg} / \mathrm{mL})$ and $37^{\circ} \mathrm{C}$ $(15.13 \mathrm{mg} / \mathrm{mL})$. When the incubation of the mixture increased from $37^{\circ} \mathrm{C}$ to $60^{\circ} \mathrm{C}$ for $30 \mathrm{~min}$, this led to a $42.4 \%$ increase of acrylamide content. 

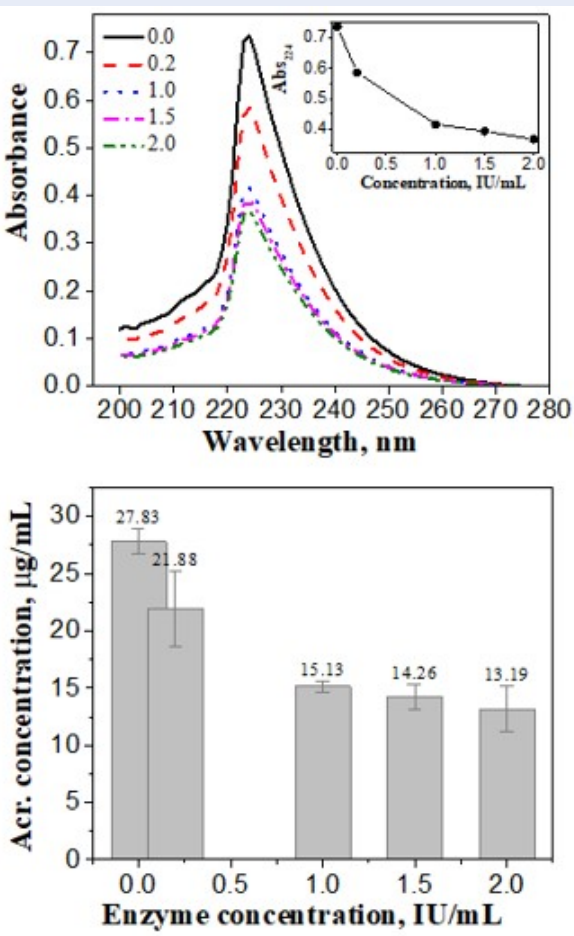

Figure 2: Top panel: The absorption spectra of samples after pre-treated with L-asparaginase in various concentrations. The inset depicted a change of absorbance values at $224 \mathrm{~nm}$ of solutions versus enzyme concentrations. Bottom panels: Acrylamide levels in potato chips as a function of enzyme dose. Visible error bars reflecting the statistical error of the process were given.
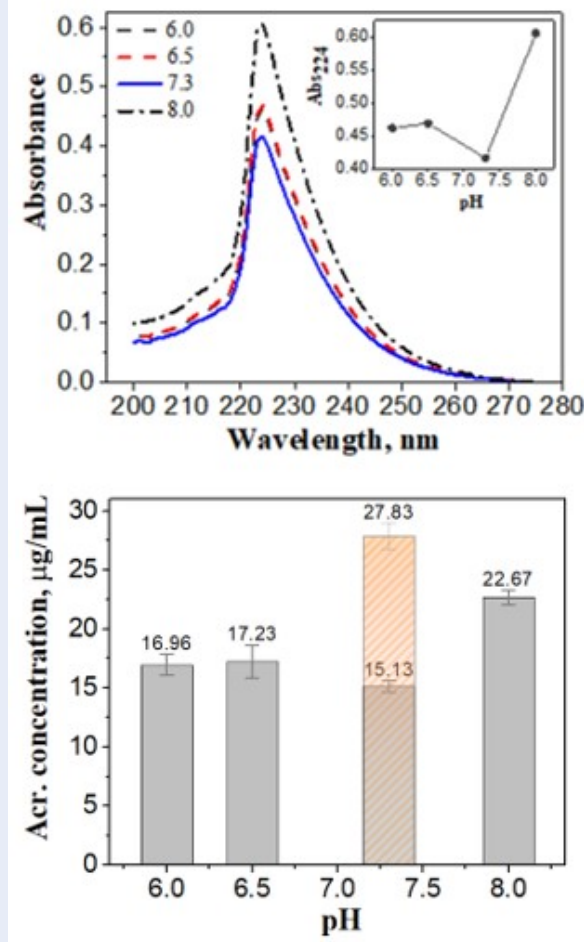

Figure 3: Top panel: The absorption spectra of samples after pre-treated with various $\mathrm{pH}$ values. The inset gave the trend of absorbance values at $224 \mathbf{~ n m}$ of solutions versus $\mathrm{pH}$. Bottom panel: Acrylamide levels with visible error bars in potato chips as a function of $\mathrm{pH}$ values of solutions. The orange bar with sparse pattern depicted the acrylamide concentration of control sample which was pre-treated at $37^{\circ} \mathrm{C}, \mathrm{pH} 7.3$ for $30 \mathrm{~min}$ with the absence of enzyme.

\section{Effects of frying time on acrylamide mitiga- tion and appearance}

By applying appropriate parameters for pretreatment, the acrylamide mitigation and the appearance of French fries under different frying times were evaluated. Even though L-asparaginase had advantages, it was estimated that the acrylamide content would increase roughly 5.6 times when frying at $190 \pm 5{ }^{\circ} \mathrm{C}$ for $6 \mathrm{~min}\left(\mathrm{Abs}_{224}=0.032\right)$, compared to the result for $1.0 \mathrm{~min}\left(\mathrm{Abs}_{224}=0.181\right)$ (top panel of Figure 5). Furthermore, the chip turned a darker color, i.e., L value decreased (Table 1). The appearance resulted in a lower quality and taste of the final product (bottom panel of Figure 5). The results of the colorspace measurements also showed that there was a clear color difference between the two samples $(\triangle E>3.5)$.

\section{DISCUSSION}

The $2.5 \% \mathrm{NaCl}$ solution was used for the pretreatment step of the potatoes. The effect of $\mathrm{NaCl}$ on the acrylamide reduction was reported in Ref. 9. Salt changes in the microstructure of potato tissue makes the diffusion of $\mathrm{NaCl}$ easier, producing some kind of inhibition in the mechanism of acrylamide formation. In our work, all samples were pre-treated with $\mathrm{NaCl}$ solution. One sample without treatment with enzyme was used as a reference sample, while the others were treated with enzyme. Therefore, the effect of $\mathrm{NaCl}$ on the acrylamide reduction in all samples was the same. The percentage of acrylamide mitigation of enzymetreated samples can be attributable to enzyme activity. Furthermore, when potatoes are immersed in $\mathrm{NaCl}$ solution, water will move from an area of less salt to more salt. Therefore, water that is inside the potato will move out by osmosis. The $\mathrm{NaCl}$-treated potatoes 
Table 1: Colorspace measurement results of potato samples

\begin{tabular}{lllll}
\hline & $\mathbf{L}$ & $\mathbf{a}$ & $\mathbf{b}$ & $\Delta \mathrm{E}$ \\
$\mathrm{S}_{0}$ & $65.97 \pm 2.17^{a}$ & $-4.36 \pm 0.16^{a}$ & $25.81 \pm 1.58^{b c}$ & 0 \\
$\mathrm{~S}_{1}$ & $63.61 \pm 0.97^{a}$ & $-4.00 \pm 0.66^{a}$ & $21.81 \pm 0.60^{a b}$ & 4.66 \\
$\mathrm{~S}_{2}$ & $64.85 \pm 1.73^{a}$ & $-0.28 \pm 0.45^{b}$ & $28.82 \pm 1.98^{c}$ & 5.196 \\
$\mathrm{~S}_{3}$ & $55.17 \pm 1.25^{b}$ & $4.40 \pm 1.27^{c}$ & $24.64 \pm 2.16^{b c}$ & 13.96 \\
$\mathrm{~S}_{4}$ & $52.16 \pm 3.57^{c}$ & $10.45 \pm 1.66^{d}$ & $26.77 \pm 6.23^{c}$ & 20.276 \\
$\mathrm{~S}_{5}$ & $43.05 \pm 1.38^{d}$ & $15.11 \pm 1.03^{e}$ & $24.48 \pm 2.61^{c}$ & 30.106 \\
$\mathrm{~S}_{6}$ & $39.52 \pm 1.08^{e}$ & $13.66 \pm 2.35^{e}$ & $19.83 \pm 3.08^{a}$ & 32.56 \\
\hline
\end{tabular}

The same letters $(a, b, c, d, e)$ in one column gave non-statistically significant difference $(\mathrm{p}<0.05) . S_{i}(i=0-6)$ refers samples after fried for various frying time (0-6 minute (s)).
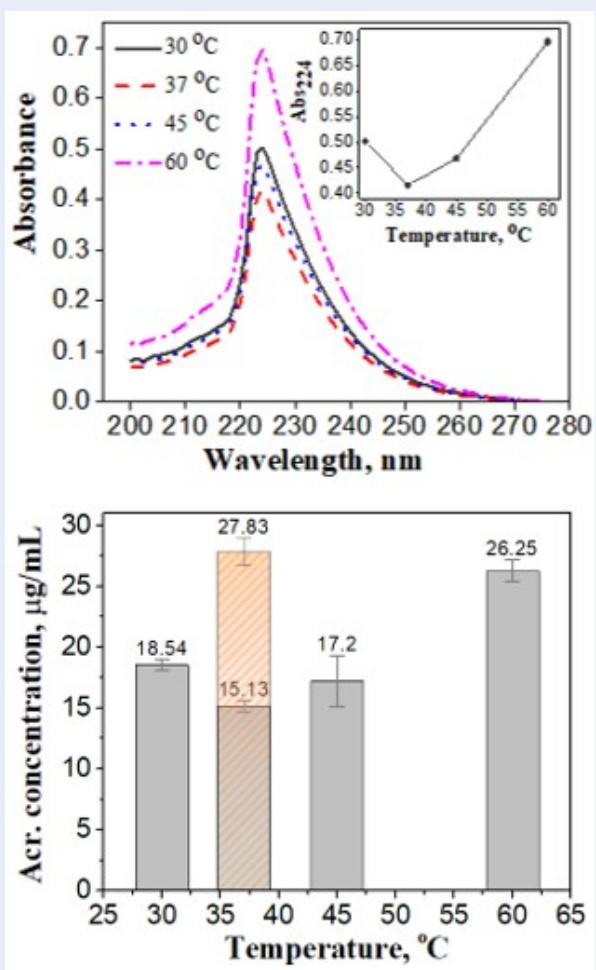

Figure 4: Top panel: The absorption spectra of samples afterpre-treated at various incubation temperatures. The absorbance values at 224 nmof acrylamide solutions versus temperatures were given in the inset. Bottompanel: Acrylamide contents (with error bars) respecting to temperatures wereshown in bottom panel. The orange bar with sparse pattern gave the acrylamideconcentration of control sample which was pre-treated at $37^{\circ} \mathrm{C}, \mathrm{pH7.3}$ for $30 \mathrm{~min}$ with the absence of enzyme.
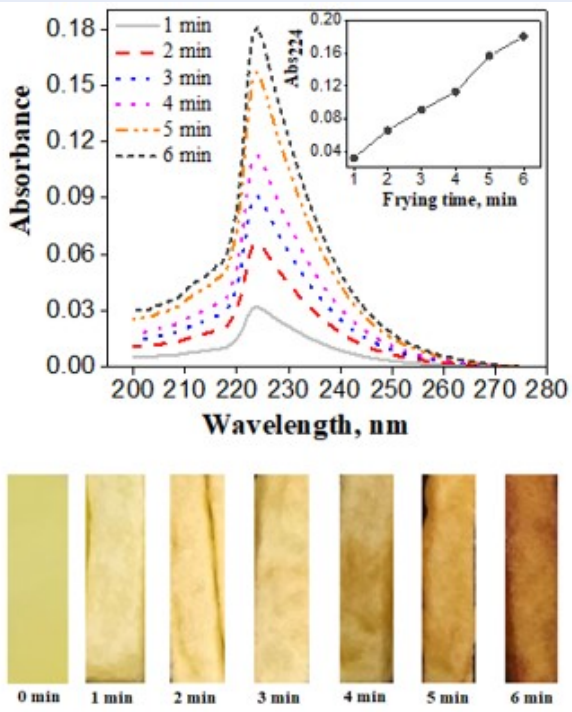

Figure 5: Top panel gave the absorption spectra of samples and the inset showing the maximum absorbance values at $224 \mathrm{~nm}$ of solutions containing acrylamide as a function of frying time. The appearance of French fries after frying within different periods at $190 \pm 5^{\circ} \mathrm{C}$ was given in bottom panel. A sample without frying was used as a reference.

were treated with enzyme in the next step. As a result, both water and enzyme would move in the potatoes by diffusion. This enhances the efficiency of enzyme absorption.

A larger reduction of acrylamide content in French fries was achieved at higher enzyme concentration $(2.0 \mathrm{IU} / \mathrm{mL})$, resulting in an approximately $52.6 \%$ decrease of acrylamide level. From heating of foods, asparagine reacts with reducing sugars (glucose, fructose, etc.) to generate acrylamide. The thermal conversion of asparagine into acrylamide can be re- 
duced by means of L-asparaginase treatment. Lasparaginase catalyzes the hydrolysis of asparagine into aspartic acid and ammonia by hydrolyzing the amide group in the side chain of asparagine, resulting in the depletion of asparagine precursor. The acrylamide reduction was diminished significantly with increasing enzyme concentrations $7,9,11,12,17$. The lowest acrylamide concentration was observed in a solution at $\mathrm{pH} 7.3$ while the highest value was obtained at $\mathrm{pH}$ 8.0. The $\mathrm{pH}$ values play a crucial role on enzyme activity. L-asparaginase is an intracellular enzyme which is found in some bacteria and its optimal activities are usually achieved in the neutral $\mathrm{pH}$ range and $37^{\circ} \mathrm{C}$. This observation could be due to the optimum $\mathrm{pH}$ of L-asparaginase activity from Escherichia coli being $7.3^{11,17}$.

The most efficient acrylamide mitigation was archived after the incubation period at $37^{\circ} \mathrm{C}$ while the enzyme activity decreased significantly at $60^{\circ} \mathrm{C}$. These results are attributable to the enzyme activity at a range of temperatures ${ }^{12}$. The L-asparaginase was seen to be most active at $37^{\circ} \mathrm{C}$. However, at temperatures above $60^{\circ} \mathrm{C}$, the enzyme activity decreased rapidly.

Frying time is one of factors which influence the acrylamide content in the final product. In general, acrylamide concentration of fried potatoes increased over a frying time of $6 \mathrm{~min}$. The greatest amount of acrylamide was formed at the surface of the material during frying time due to the highest temperature being on the surface. Increasing the frying time from 1 to 6 min caused an even greater increase (by a factor of 5.6) in acrylamide concentration in the fried potatoes. This observation can be attributed to the fact that when frying time increased, the potatoes were exposed longer at high temperature and, thus, heat transfer occurred and developed in the interior. As a result, more acrylamide is generated when increasing the frying time of potatoes ${ }^{18}$. Maillard non-enzymatic browning reactions produce desirable color, flavor and aroma production. However, in some situations, the formation of brown colors can be undesirable. Frying time increases the contents of undesirable compounds which are responsible for the rancidity and appearance of the product. Here, the optimum frying time of $3.0 \mathrm{~min}$ was found to have a desirable appearance of product.

\section{CONCLUSIONS}

Number of pre-treatment factors influence the acrylamide mitigation in fried potatoes, including the dose of the enzyme, $\mathrm{pH}$, incubation temperature and frying time, which were all evaluated. Pre-treating potatoes with asparaginase in a solution of $1.0 \mathrm{IU} / \mathrm{mL}$ (at $37^{\circ} \mathrm{C}, \mathrm{pH} 7.3$, for $30 \mathrm{~min}$ ) led to an approximately $45.6 \%$ decrease of acrylamide concentration in the final product. L-asparaginase significantly reduced the amount of asparagine by converting this precursor into aspartic acid and ammonia. By systematically varying $\mathrm{pH}$ values and incubation temperatures, a mitigation of acrylamide content was achieved in products under appropriate $\mathrm{pH}$ and temperature of 7.3 and $37^{\circ} \mathrm{C}$, respectively. Furthermore, the frying time was found to impact the acrylamide formation. When potato strips were immersed for $30 \mathrm{~min}$ and fried for $3 \mathrm{~min}$, the acrylamide level was mitigated and the product appearance was found to be desirable. The simple experiments developed so far may reduce acrylamide levels in fried potatoes, as studied by us under the varying laboratory conditions, and might benefit the commercial processes involving potato preparations. However, the application of enzyme on acrylamide reduction process should retain other quality aspects and consumer acceptability. Therefore, further work is necessary to explore the possible effects of asparaginase on the products from potatoes.

\section{LIST OF ABBREVIATIONS}

UV-Vis: Ultraviolet-visible

Abs: Absorbance

\section{COMPETING INTERESTS}

The authors declare that they have no competing interests.

\section{ACKNOWLEDGEMENT}

Ho Chi Minh City University of Technology and Education is gratefully acknowledged by providing the facilities necessary to complete this project.

\section{REFERENCES}

1. Tareke E, Rydberg P, Karlsson P, Eriksson S, Törnqvist M. Analysis of Acrylamide, a Carcinogen Formed in Heated Foodstuffs. J Agric Food Chem. 2002;50(17):4998-5006. PMID: 12166997. Available from: https://doi.org/10.1021/jf020302f.

2. Rosén J, Hellenäs KE. Analysis of acrylamide in cooked foods by liquid chromatography tandem mass spectrometry. The Analyst. 2002;127(7):880-882. PMID: 12173642. Available from: https://doi.org/10.1039/b204938d.

3. Wilson KM, Rimm EB, Thompson KM, Mucci LA. Dietary Acrylamide and Cancer Risk in Humans: A Review. J Für Verbraucherschutz Leb. 2006;1(1):19-27. Available from: https: //doi.org/10.1007/s00003-006-0005-6.

4. Mottram DS, Wedzicha BL, Dodson AT. Acrylamide is formed in the Maillard reaction. Nature. 2002;419(6906):448-449. PMID: 12368844. Available from: https://doi.org/10.1038/419448a.

5. Stadler RH, Blank I, Varga N, Robert F, Hau J, Guy PA, et al. Acrylamide from Maillard reaction products. Nature. 2002;419(6906):449-450. PMID: 12368845. Available from: https://doi.org/10.1038/419449a. 
6. Coughlin JR. Acrylamide: What We Have Learned So Far. Food Technol. 2003;57(2).

7. Yaylayan VA, Wnorowski A, Perez LC. Why Asparagine Needs Carbohydrates To Generate Acrylamide. J Agric Food Chem. 2003;51(6):1753-1757. PMID: 12617619. Available from: https://doi.org/10.1021/jf0261506.

8. Pedreschi F, Kaack K, Granby K. Acrylamide content and color development in fried potato strips. Food Res Int. 2006;39(1):40-46. Available from: https://doi.org/10.1016/j. foodres.2005.06.001.

9. Zyzak DV, Sanders RA, Stojanovic M, Tallmadge DH, Eberhart BL, Ewald DK, et al. Acrylamide Formation Mechanism in Heated Foods. J Agric Food Chem. 2003;51(16):47824787. PMID: 14705913. Available from: https://doi.org/10. 1021/jf034180i.

10. Amrein TM, Schönbächler B, Escher F, Amadò R. Acrylamide in Gingerbread: Critical Factors for Formation and Possible Ways for Reduction. J Agric Food Chem. 2004;52(13):42824288. PMID: 15212481. Available from: https://doi.org/10. 1021/jf049648b.

11. Ciesarová Z. Impact of I-Asparaginase on Acrylamide Content in Fried Potato and Bakery Products. In: Acrylamide in Food [Internet]. Elsevier; [cited 2020 Mar 28]. 2016;p. 405-421. Available from: https://linkinghub. elsevier.com/retrieve/pii/B9780128028322000218https: //doi.org/10.1016/B978-0-12-802832-2.00021-8.

12. Pedreschi F, Kaack K, Granby K. The effect of asparaginase on acrylamide formation in French fries. Food Chem.
2008;109(2):386-392. PMID: 26003362. Available from: https: //doi.org/10.1016/j.foodchem.2007.12.057.

13. Amrein TM, Bachmann S, Noti A, Biedermann M, Barbosa MF, Biedermann-Brem S, et al. Potential of Acrylamide Formation, Sugars, and Free Asparagine in Potatoes: A Comparison of Cultivars and Farming Systems. J Agric Food Chem. 2003;51(18):5556-5560. PMID: 12926914. Available from: https://doi.org/10.1021/jf034344v.

14. Pedreschi F, Mariotti S, Granby K, Risum J. Acrylamide reduction in potato chips by using commercial asparaginase in combination with conventional blanching. LWT - Food Sci Technol. 2011;44(6):1473-1476. Available from: https://doi. org/10.1016/j.lwt.2011.02.004.

15. Dange VU, Sakhale BK, Giri NA. Enzyme Application for Reduction of Acrylamide Formation in Fried Potato Chips. Curr Res Nutr Food Sci J. 2018;6(1):222-226. Available from: https: //doi.org/10.12944/CRNFSJ.6.1.25.

16. Mokrzycki WS, Tatol M. Color difference $\Delta \mathrm{E}$ - A survey. Mach Graph Vis. 2011;20(4):383-411.

17. Xu F, Oruna-Concha MJ, Elmore JS. The use of asparaginase to reduce acrylamide levels in cooked food. Food Chem Nov. 2016;210:163-171. PMID: 27211635. Available from: https: //doi.org/10.1016/j.foodchem.2016.04.105.

18. Gökmen V, Palazoğlu TK. Measurement of evaporated acrylamide during frying of potatoes: Effect of frying conditions and surface area-to-volume ratio. J Food Eng. 2009;93(2):172176. Available from: https://doi.org/10.1016/j.jfoodeng.2009. 01.011 . 